\title{
The Intertwining of Educational Dualism in post-New Order Indonesia
}

\author{
Suzanna Eddyono \\ Department of Social Development and Welfare (PSdK), Faculty of Social and Political Sciences, \\ Universitas Gadjah Mada \\ (Email: sused132@gmail.com)
}

\begin{abstract}
This study focuses on continuities and changes in the dualism of national education after the collapse of the New-Order Regime in 1998. It argues that the Indonesian dualism of education may serve as a significant context in shaping the existing tensions in citizenship education in postNew-Order Indonesia. Drawing from a thematic analysis of citizenship education documents, related policy, and interviews with authors and higher education teaching staff, this study echoes the latest observations that reveal a more intertwining than rigid separation of the continuing dualism of national education. Yet, unlike the previous studies that reveal the tensions in more Islamic-based education, in its response to a more secular and modern demand, this study further highlights the intertwining of the dualism of education palpable in the citizenship education policy in post-New-Order Indonesia. It further calls for policy makers and educators to evaluate the existing citizenship education curriculum and its implementation within the context of an intertwined educational dualism in Indonesia. As such, this paper further aims to highlight the urgency of considering broader cultural and political contexts and actors involved in the process of reproducing official narratives of Indonesianess in the national curricula.
\end{abstract}

\section{Keywords:}

education policy; post-New Order Indonesia; contesting values; citizenship education; higher learning institutions

\section{Introduction}

The national education system in Indonesia is characterized by dualism (Azra, 2007; Buchori \& Malik, 2004; Sirozi, 2004, and Raihani, 2014). The dualism is manifested in the existence of two coexisting administrations and two types of education: a more secular learning education system administered by the Ministry of Education and an Islamic learning education system administered by the Ministry of Religious Affairs. Each Ministry is responsible for administering education at all levels, right from elementary to the institutions of higher learning.

The Islamic education evolved from the traditional pesantren, an Islamic traditional boarding school system. Prior to the establishment of the national education, the Islamic traditional institutions were the main educational establishments for the indigenous Indonesians (Buchori \& Malik, 2004). Thus, such schools were administered separatedly from the Christian schools funded by the VOC and later by the Dutch colonial regime (Groeneboer, 1993). However, from the 1930s, many pesantren adopted governmentrecognized curricula and in the 1970s, Islamic schools adopted a curriculum that combined Islamic religious teachings with secular and modern based knowledge, such as science and math (Lukens-Bull, 2001, pp. 353-354). 
This was endorsed by a joint decision of three government ministries ${ }^{1}$ that regulated that in religious-based school (madrasah) the curricula must contain $70 \%$ of more general/ secular teaching and $30 \%$ of religious subjects (Raihani, 2014; Murray, 1988). The decision was intended:

"to make the diploma from a madrasah equal in value to the diploma from general secular schools, to enable graduates of madrasah to enter secular institutions of the next higher level in the schooling hierarchy, and to equip students in madrasahs for transfer into secular school and vice versa" (Murray 1988, p. 906)

Currently, students in Islamic institutions learn secular-modern science (Hefner, 2010; Jackson \& Bahrissalim, 2007; Lukens-Bull, 2001) and participate in national exams that are administered by the Ministry of National Education (Parker \& Raihani, 2011). Today, Islamic institutions play an important role in providing schools in Indonesia with teachers of Islamic studies and ulama, whose influence is discernible from their interpretation of Islamic teachings (Jackson \& Bahrissalim, 2007, p. 349). Many of their graduates also occupy positions as staff in bureaucracy at various levels of government.

While the Islamic based traditional education emerged prior to the formation of the nation-state, the more general and secular education was established in the aftermath of the establishment of the Ministry of Education shortly after the new state was proclaimed in 1945. Secular education adopted modern curricula that laid emphasis on the acquisition of knowledge and skills, preparing students to embrace modernity and national values, and to a limited extent, offered a religious education course as one of the mandated

\footnotetext{
1 The three ministries were the Ministry of Education and Culture, the Ministry of Religion, and the Ministry of Interior.
}

subjects. Since the implementation of the 2003 Education Law and the 2013 national education curricula, the number of general schools offering religious-related school activities and values has increased.

By highlighting the complexity of the Indonesian national education system, this paper is attempting to examine the impact that persisting dualism in education may have on citizenship education during the Post-New Order $^{2}$ era. The implementation of citizenship education in many parts of the world, in general, has two goals: to produce "a culturally and nationally homogeneous labor force," and to promote active, democratic, autonomous, critical citizens (Bénêi, 2005, p. 9). This paper argues that the dualism of education in Indonesian higher education provides an important context that will complicate efforts to create a single official narrative of the nation and the ideal citizens. Consistent with that argument, the educational dualism has the potential to contribute to the intensification of contestation and tensions in the narrative of citizenship education in Indonesia. By contextualizing the implementation of citizenship education policy within the intertwining of dualism of education in post-New Order Indonesia, this paper aims to highlight the urgency of considering the broader cultural and political contexts and actors involved in the process of representing the nation and good citizens in the national curricula.

The following discussion is divided into several parts. After methods, the following section presents an outline of data collection and analysis, with the supporting rationale for the choice of methods to draw insights that support the argument above.

\footnotetext{
2 The author uses the term post-Suharto and post-New Order interchangeably. Both refer to the period after the regime change in 1998, when Suharto, after more than 30 years in power, stepped down following democratization movement since the early 1990s.
} 


\section{Methods}

This paper focuses on citizenship education policy in higher education in general. The research collected three sources of both primary and secondary data. The first source was a set of in-depth interviews between 2012 and 2017 with five authors of citizenship education textbooks in Medan, Yogyakarta, and Malang, who were selected based on the author information page in selected citizenship education textbooks. The next primary data source was one face-to-face interview and three phone interviews with the staff of local and national publishers of citizenship education textbooks. Meanwhile, the third primary data source entailed in-depth interviews with twelve educators from four universities (UDA, UNIMED, USU, UMSU) in Medan, three educators from UGM and UNY in Yogyakarta. In addition, secondary data consisted of thirty-five policy documents that contained regulations between 1954 and 2017 on citizenship education in Indonesia as well as national curricula that are deemed to have contributed to shaping the practice and the content of citizenship education in higher education.

The paper adapts Riessman's thematic analysis (2008), that emphasizes "thematic meanings" and "point" to gain "specificity" (2008, pp. 62-64). After reading through the citizenship education-related documents, the method of analysis made possible the identification of the gap between thematic expectations of publishers, writers and educators, and the developments and trajectory in government policy on what constitutes an ideal citizen by post New Order government. A similar thematic analysis is used for both primary and secondary data, to explore how the content of citizenship education is reproduced and how citizenship education books are selected for university students.

\section{Results}

\section{The Intertwining of Educational Dualism in post-New Order Indonesia}

After the rejection of the Jakarta Charter ${ }^{3}$ in 1945, the government of the day established the first Islamic higher institution (STI) in 1946. An argument is often made that the establishment of STI marked "the beginning of the competition" between Muslims and nationalists in the national education system (Buchori \& Malik, 2004, p. 266).

A major shift in the national educational policy took place after 1998. Prior to the national

\footnotetext{
3 Prior to the Indonesian independency, in a BPUPKI (the Independence Preparatory Committee or Badan Penyelidik Usaha Persiapan Kemerdekaan Indonesia) meeting on June 1, 1945, Sukarno proposed "Pancasila", that literally means five pillars or five principles. The five tenets that Sukarno proposed consisted of (1) Indonesian nationhood or Indonesian nationalism (2) internationalism/humanitarianism (3) unanimous consensus or democracy (4) social justice, and (5) the belief in one God. On June 22, 1945, Islamic leaders proposed to insert the later famous seven words "... with the obligation to carry out sharia among Muslims" after Sukarno's fifth tenet of the "belief in one God" (Ramage, 1995, p. 14; Picard, 2011, p. 94). In addition, they demanded to include Pancasila with the insertion of the seven words, in a draft of preamble to the Constitution. The draft, known as the Jakarta Charter, was later accepted by BPUPKI (Elson 2009). However, on August 18, 1945, a day after the announcement of the Indonesian independence by Sukarno, the groups of nationalists and non-Muslim leaders approached Mohammad Hatta, expressing their rejection to the additional sentence. Hatta later convinced PPKI, a small committee appointed by BPUPKI to omit the seven words from the final draft of the preamble and from the article 29 on religion in the constitution (Elson, 2009, p. 120). As a result, Sukarno's final version of Pancasila included belief in God, humanity, unity, democracy, and social justice. As the concession to the Islamic groups for accepting the rejection of the Jakarta Charter, the new government established the Ministry of Religion in January 1946 (Picard, 2011, p. 13). However, in the 1968 another demand concerning the Jakarta Charter reemerged. Whereas in the 1940s and 1950s the demands were to insert the seven words, the obligation to carry shariah among Muslims, after the first principle of Pancasila and in the preamble of the 1945 constitution; in the 1968, an attempt was made to insert the seven words back in the article 29 of the Constitution (Ramage, 1995). Again, this effort was rejected.
} 
assembly meeting, in 2002, the members of the Parliament from PPP, an Islam-affiliated party, attempted to resurrect the possibility of discussing the Jakarta Charter, which would obligate Indonesian Muslims to adhere to shariah tenets and principles. However, the proposal failed to gain significant support from other members of parliament and "was withdrawn without a vote" (Liddle \& Mujani, 2013, p. 31).

As a concession to the Islamists, the national consultative council assembly (MPR) approved changes to the Constitution ${ }^{4}$, that obliged the government, among other things, to enhance "faith and piety" in education through the Education Bill, that was later to become the Education Law No. 20/2003 (Yusuf \& Sterkens, 2015; Raillon, 2011, p. 94). The law indicates that national education has moved from more secular to more religious policies (Yusuf and Sterkens 2015). For example, not only does the 2003 Education Law regulate that religious education is compulsory and must be taught by instructors of the same faith with students ${ }^{5}$, it also puts more emphasis on piety as one of the aims of national education.

When analyzing the deliberations process of the Law No. 20/2003 on national education, Yusuf and Sterkens (2015) highlight the large extent to which Islamic values informed the plenary meeting of the People's Consultative Assembly (MPR). In rendering their support

\footnotetext{
${ }^{4}$ Chapter XIII on Education and Culture, Article (3), point 3

5 This practice is not new, the necessity to enact the law calls for two possible explanations. One is related to the anxiety among Muslim leaders pertaining to the practice in Christian schools that did not provide Muslim religious education for Muslim students, although similar practices are not rare in numerous Islam-based institutions. There is a concern, that the law is directed mainly to push Catholic and Protestant schools to provide religion education for their Muslims students (Raillon 2011). Another possible explanation is linked to the attempt to govern citizens' behavior, to keep them in line with their religious community. This is visible in the Government Regulation No. 55/2007 and the Regulation No. 16/2010 of the Ministry of Religious Affairs following the 2003 education law (Yusuf and Sterken 2015).
}

to the bill that later became the education law, six out of nine political party factions made explicit reference to the Hadith and the Quran. Islamist parties, for example PBB, argued that approving the 2003 education bill "was consistent with and represented the national ideology of Pancasila and Constitution amendment 2002, particularly with regard to the need to include religious values" (Yusuf \& Sterkens, 2015, p. 122). In addition, the spokesperson, K.H. Nadjih Ahjat, underscored the importance of the national education to consider intellectual aspects, religious commitment, religious devotion, and students' noble character (Yusuf \& Sterkens, 2015, p. 121).

Nonetheless, prior to the implementation of The Education Law No. 20/2003, the government had begun to shift its attitude toward Islamic schools. While during the New Order regime, the Islamic higher institution was constrained to teach only religious sciences (Azra, 2007), since 2002 the post-New Order government has facilitated and supported the transformation of Islamic institutions under the Ministry of Religion Affairs (MoRA) into Islamic universities that fall under the Ministry of Education (MoE). The institutional change begun with Syarif Hidayatullah State Islamic Institute in Jakarta (UIN Jakarta) (Azra 2007), and later in 2004 the change was to be followed by the Sunan Kalijaga State Islamic Institute in Yogyakarta (UIN Yogyakarta) (Jackson \& Bahrissalim, 2007, p. 44). By transforming from an Islamic institute into a university, the institution changes its structures, curricula, including the establishment of new departments, such as economics, engineering and medicine (Azra, 2007). Consequently, the conduct of teaching and management of Islamic universities must be based on regulations and standards set by both the Ministry of Religion and the Ministry of Research, Technology, and Higher Education. ${ }^{6}$

${ }_{6}$ The Ministry of Research, Technology, and Higher 
One of the issues that several studies have identified in the transition from Islamic institutions (IAIN and STAIN) into Islamic universities is that there is the rising tension in the curricula in Islamic schools and universities regarding the national ideology and modernsecularism (Azra, 2007; Hefner, 2010). The tension is evident, for instance, among the educators in the Islamic state institution (IAIN), who find it uneasy to reconcile curriculum changes, that attempt to combine "students' academic exercises and advancement in religious knowing" and "students' character and religiosity" (Azra, 2007, p. 259). With the religious mission of IAINs, those who disagree with efforts to transform Islamic institutions into universities that:

"Islamic education would serve the needs of the government and community in accordance with the Jakarta Charter of June 22, 1945, which was initially intended to be an inseparable part of the 1945 Constitution. In other words, there was a religious mission underlying the establishment of this higher learning institution. IAINs are expected to produce quality human resources to staff the public religious bureaucracy and to serve as preachers. Consequently, as the argument goes, it would be more natural for IAINs to develop into institutes of Islamic studies, rather than into universities" (Buchori \& Malik, 2004, p. 266)

Despite the palpable tension in Islamic institutions today, a number of studies have highlighted the development of "a hybrid system of education" that combines the traditional religious teaching and modern

Education was formed in 2015. Previously, higher education was administered under the Higher Education Directorate (Dikti) that structurally was under the Ministry of Education (MoE). Currently, the MoE administers primary and secondary level of general/more secular education in Indonesia. "scientific and technical training" in Islamic institutions (Lukens-Bull, 2001, p. 368). Rather than resisting modernity, a pesantren in Malang for instance, has set the goal "to (re)inventing a distinctly Islamic modernity for Indonesia" by (re)inventing its Islamic tradition and making changes which are expected to appeal to college students from relatively more secular curricula institutions. What the modern Islamic institution is trying to achieve is also substantiated by Jackson and Parker (2008): "Islamic schools have been concerned to provide their students with access to 'modern knowledge', while at the same time containing it and subsuming it to the higher truth of Islamic knowledge" (p. 38).

Most importantly, the Post-New Order Indonesia has witnessed the emergence of "a new breed of Islamic schools" (Hefner, 2010 , p. 126). One of these can be seen from an integrated Islamic school system that was founded by the Islamic Party Hidayah ${ }^{7}$ in 2007. In a series of interviews with some of the educators, Hefner reveals disagreement between school educators who claim that "for the time being, the foundation of the state can be nationalist by orientation" and school textbooks that consider current democracy and nationalism as "un-Islamic" (Hefner, 2010, p. 136-138).

Interestingly, some previous studies have also highlighted the unprecedented dissemination of Islamic values within general curricula schools. A study by Rosidin (2013), for example, demonstrates how a Salafi-influences movement to Islamize society was inserted by Rohani Islam by inculcating Islamic ideals into two state secondary school students in Cirebon (SMAN 04 and SMAN 06). After several years of the organization activities in the two schools, as Rosidin argues, the behavior of students in the two schools has changed as follows:

\footnotetext{
7 According to Hefner (2010), this organization has a close ideological link with an Islamic party (PKS) and has built 133 integral Islamic schools since 2007.
} 
"Not a single female student wears short trousers and a majority wears a jilbab during physical education. Inside the classrooms, male and female students are separated and have different rows of desks. This is, of course, in contrast with the past, when male and female students would share tables" (p. 218).

Rosidin (2013) notes that the success of the Rohani Islamic movement owes much to the support from the school, students, school board and the influence of religious teachers and their dakwah network movement outside the two schools.

Apparently, as most students are Muslims, in many cases, more religious attitudes mean more explicit demand for the practice of Islamic values. In Lubuk Pakam -an hour ride from Medan, a primary public school begins the class by praying in Islamic way despite some of its students are Christian. In Yogyakarta, students in some of primary and secondary public schools are encouraged to come earlier to practice praying (shalat dhuha) and Quran recital before school starts. In addition, a distinction between attributes for Muslims and Non-Muslims is visible from student's uniform. The latter is closely related to schools' strong persuasion that Muslim female students in public schools should wear "jilbab", a practice that was unthinkable three decades ago, when girls were instead prohibited to do so in public school.

What can be drawn from the above studies and ilustrations, is that, despite the dualism in the educational systems that indicates boundaries that separate Islamic institutions and the ones that have relatively secular curricula; in practice, the dualism does not simply reflect the mutual exclusivity of the two educational systems. Separate administrations do not straightforwardly reflect whether the administered school or universities are religious-based or more secular.
Religious-based institutions can be registered to and administered under the Ministry of Education, and in what are considered as more secular schools or universities, the adaptation of religious practices endorsed by the 2013 national curricula may shape the school everyday activities.

To that end, with the concept of the intertwining of educational dualism, it is possible to shed light on the competing knowledge and values as well as the cross cutting ideas, ideals, and regulations that link the two systems. Therefore, the concept of the intertwining of educational dualism highlights the fallacy of categorizing schools on the basis of whether they are registered in the Ministry of Education (secular schools) or Ministry of religious affairs (religious schools). The concept is also potential to be used to capture and explore interactions among actors, networks development, and collaborations, that transcend physical school sites and educational arena. Equally important, as the following sections demonstrates, the concept is useful for contextualizing the emerging tension and contestation in citizenship education in post-New Order Indonesia.

\section{Citizenship education in post-New Order Indonesia}

Like all levels of education, Indonesian universities are required to offer four compulsory courses that include religion, citizenship education, Indonesian language (Bahasa Indonesia), and Pancasila education. The Law No. 12/2012 on National Education considered the four subjects as compulsory subjects in the national curricula toward serving the goal of national building. As an integral component of the state's attempts to "Indonesianize" Indonesians, civic education has evolved through several regulations from Civics between 1957 and 1962; Social Education (Pendidikan Kemasyarakatan), which integrated history, geography, and citizenship since 
1964; and Citizenship Education (Pendidikan Kewargaan Negara) from 1968 to 1969. A long the way, the teaching of civic education took the form of Citizenship, Civics, and Law class since 1973; Pancasila Moral Education (Pendidikan Moral Pancasila/PMP) from 1975 to 1984, and Pancasila and Citizenship Education (Pancasila dan Pendidikan Kewarganegaraan/PPKN) since 1994.

For more advanced education, the Manipol $^{8}$ and USDEK ${ }^{9}$, Pancasila and the 1945 constitution course became obligatory in 1960s (Ubaedillah \& Rozak, 2012). Moreover, students were required to undergo military training (known as Wajib Latih Mahasiswa (Walawa) (Lemhanas, 1992). In the 1973-1974 academic year, Suharto's New Order regime made studying Pancasila Philosopy (Filsafat Pancasila) a compulsory course for students. Subsequently, in 1983, the government includes patriotism education (Pendidikan Kewiraan) on the list of curricula as a compulsory course (Jackson \& Bahrissalam, 2007, p. 45). The New Order regime also launched the $P 4^{10}$ program, which required university students to attend at least one-week of lectures and discussions, that were aimed at strengthening their sense of nationalism and improving their understanding of Pancasila.

Since 1994, the government embarked on the policy of decentralizing education with the professes goals of enhancing autonomy of schools and universities, including formulating their local curricula. In 1998, the shift in the locus of school management was reflected in improvements in educational system governance that has since become more democratic. The

\footnotetext{
8 Manipol is the abbreviation for Manifesto Politik (Political Manifesto).

9 USDEK is the abbreviation for Undang-Undang Dasar 1945, Sosialisme Indonesia, Demokrasi Terpimpin, Ekonomi Terpimpin, and Kepribadian Indonesia (the 1945 Constitution, Indonesian Socialism, Guided Democracy, Guided Economics, and Indonesian Personality/ Character).

${ }^{10} \mathrm{P} 4$ is the abbreviation for Pedoman, Penghayatan dan Pengamalan Pancasila (the Guide to the full comprehension and practice of Pancasila)
}

above changes have led to the transformation of citizenship education. Between 1998 and 2005, the government required university students to take a citizenship education course, ${ }^{11}$ and in the following year, a new regulation drew a list of themes that textbooks on citizenship education for students in higher education had to cover. ${ }^{12}$ Six years later in 2012, the Ministry of Education not only re-inserted Pancasila as an additional course but also reinstated citizenship education as a compulsory subject. ${ }^{13}$

Continuing the tradition of considering national education as vital for national building, the Ministry of Education has repositioned civics as one component for the core curriculum (Mata Kuliah Inti/MKI) in higher education. It has also attempted to alter the approach and curricula in line with the political discourses of democracy, human rights, and regional autonomy. Contrary to the New Order regime that employed military style and indoctrination driven approaches that emphasized teacher-centered methods, the new citizenship education is expected to encourage and promote participatory teaching methods (Jackson \& Bahrissalam, 2007, p. 4647). Consequently, the government has raised the qualifications that citizenship education educators must have. During the NewOrder regime, National Defense Institution

\footnotetext{
${ }^{11}$ See the Decision Letter of the Ministry of National Education No. 232/U/2000 about the guidance for the formulation of the higher education curricula and assessment of student's learning outcome, particularly article 10 and the article 3 of the Decision Letter of the General Director of the Higher Education of the Ministry of National Education No. 38/DIKTI/Kep/2002 about the guidance for character development course at university; the Law No. 20/2003 about the national education system, article 37; and the government regulation No. 19/2005 about the standard of national education, particularly in article 9.

${ }^{12}$ The Decision Letter of the General Director of the Higher Education of the Ministry of National Education No. 43/DIKTI/Kep/2006 about the guidance for the character development in higher education, particularly article 4 .

${ }^{13}$ The Law No. 12/2012 about Higher Education, on article 35.
} 
Table 1.

The Numbers of Citizenship Education Programs, Teaching Staff, and Students Enrolled at the Undergraduate and Graduate Levels in Indonesia in 2017

\begin{tabular}{lccc}
\hline \multicolumn{1}{c}{ Level of Education } & $\begin{array}{c}\text { Citizenship } \\
\text { Education Programs }\end{array}$ & Teaching Staffs & Students \\
\hline Undergraduate (Bachelor/S1) & 128 & 1,614 & 28,493 \\
Graduate (Master/S2) & 7 & 34 & 199 \\
Graduate (PhD/S3) & 1 & 6 & 46 \\
\hline
\end{tabular}

Source: Unpublished data, obtained from the Center of Data for Higher Education (Pangkalan Data Pendidikan Tinggi/PDDikti), the Ministry of Technology and Higher Education (Menristekdikti) of the Republic of Indonesia, September 2017 (Eddyono 2018, p. 162)

(Lemhanas) was charged with formulating and implementing citizenship education ${ }^{14}$. In post-New Order Indonesia, despite efforts by Lemhanas' to maintain its role, Dikti under the Ministry of Research, Technology and Higher Education of the Republic of Indonesia bears that responsibility. Through Dikti, the government has encouraged various state and private universities to open citizenship education programs for undergraduate and graduate students who are expected to fill teaching posts ${ }^{15}$ across the country.

Most importantly, citizenship education programs at the bachelor's and master's level have been established in various state-funded Islamic and private universities. Thus, the supply of teaching staff no longer depends on military personnel or trainees of Lemhanas as was the case during the New Order period. Today, there are at least five state-funded universities that play important roles in the development of citizenship education in postNew Order Indonesia, including Universitas Terbuka, Universitas Pendidikan Indonesia, Universitas Negeri Yogyakarta, Universitas Negeri Malang, and Universitas Negeri Jakarta.

\footnotetext{
${ }^{14}$ This included Lemhanas' courses that the invited teachers of citizenship education had to attend and its appointment of military personnel to fill the position as instructors of patriotism education in various universities nationally.

${ }^{15}$ Graduates of social or law programs may also enroll as prospective educators of the citizenship education course.
}

However, despite the increase in the number of institutions of higher learning that are offering a citizenship education program, sufficient evidence indicates lack of uniformity in both course content and practice (Eddyono, 2018; Jackson \& Bahrissalam, 2007). In North Sumatera, for example, a closer look at core citizenship education curricula in three universities ${ }^{16}$ in Medan reveals differences in core courses offered despite the fact that all universities use the national curricula as their source and guidance.

Most importantly, the post-New Order citizenship education witnesses the publications of various citizenship education textbooks. In 2001, a new citizenship education textbook, Pendidikan Kewarganegaraan (Citizenship Education), was published collaboratively by Lemhanas and Dikti and was reprinted every year until 2008 (Eddyono, 2018). Lemhanas and Dikti, however, are no longer the only actors reproducing the discourse of the nation and the ideal citizen. Since 2000 a state-funded Islamic institution, UIN Jakarta has initiated a new citizenship education curriculum. In addition, a private Islamic-based university, Muhammadiyah University in Yogyakarta,

\footnotetext{
${ }^{16}$ Universitas Negeri Medan (Unimed), Universitas Muhammadiyah Sumatera Utara (UMSU), and Universitas Dharma Agung (UDA). In North Sumatera alone, citizenship education programs are offered in seven universities: five universities in Medan and two universities in Pematang Siantar (about a-four-hour drive from Medan).
} 
Table 2.

Variation in Core courses in Pancasila and Citizenship Education Programs in Three Universities in Medan, Indonesia

\begin{tabular}{|c|c|c|c|}
\hline University & Unimed & UMSU & $U D A$ \\
\hline Department & $\begin{array}{c}\text { Department of } \\
\text { Pancasila and Civics }\end{array}$ & $\begin{array}{c}\text { Department of } \\
\text { Pancasila and Civics }\end{array}$ & Department of Civics \\
\hline Core courses & $\begin{array}{ll}\text { i. } & \text { Pancasila Education } \\
\text { ii. Pancasila Philosophy } \\
\text { iii. } \\
\text { iv. Pivics } \\
\text { Planning for Teaching } \\
\text { Education } \\
\text { v. Evaluation of Pancasila and } \\
\text { Civic studies learning } \\
\text { vi. Capita Selecta of Civics. } \\
\text { vii. Research on Civics } \\
\text { viii. Ecology and Civics } \\
\text { ix. English for Civic Education } \\
\text { x. The Sociology of } \\
\text { Citizenship }\end{array}$ & $\begin{array}{ll}\text { i. } & \text { Pancasila Education } \\
\text { ii. } & \text { Pancasila Philosophy } \\
\text { iii. } & \text { Civics } \\
\text { iv. } & \text { Planning for Teaching Pancasila } \\
\text { and Civic Education } \\
\text { v. }\end{array}$ & $\begin{array}{l}\text { i. The Philosophy of } \\
\text { Pancasila } \\
\text { ii. Curriculum and Civic } \\
\text { textbooks } \\
\text { iii. Civics } \\
\text { iv. Civics I } \\
\text { v. Civics II } \\
\text { vi. }\end{array}$ \\
\hline
\end{tabular}

Source: Interviews conducted in November 2012 and January 2013 with the directors of Pancasila and Civic Education Programs at Unimed, UMSU, and UDA (Eddyono, 2018, p. 164)

has adopted the initiative in 2001, through a knowledge sharing with the team from UIN Jakarta. In 2003, Muhammadiyah University has also begun to publish its distinct version of citizenship education textbook that was different from the UIN version (Jackson \& Bahrissalam, 2007; Eddyono, 2018). Invariably, various citizenship education textbooks were published by numerous other authors. As a comparison, based on national library online catalogue by 2013 , there were 465 records of civics related textbooks published after 1998, with at least 141 titles of which were on citizenship education for university students (Eddyono, 2018). This is in stark contrast to the single citizenship education textbook that is credited to Lemhanas during the New Order regime.

It is not surprising that the large number of textbooks and contents has raised concerns among policy makers. As a response, since 2006 the government began to regulate the content of citizenship education textbooks. Based on the government regulation, the citizenship education textbook for university students should contain themes of democracy, human rights, national identity, the amendment of the 1945 constitution, national resilience, and the nationalist outlook and disposition. To supplement the foregoing, in 2012, the Directorate of Higher Education (Dikti) published the first complete online module on citizenship education. The module has a detailed syllabus for both university students and teaching staff and re-issued in 2016 after the fusion of Dikt $i$ into the Ministry of Research and Higher Education.

It also becomes obvious that the government is no longer the only actor that shapes citizenship education content and practice. Various actors involved in textbook productions include publishers with their market and demand considerations. As citizenship education textbooks are targeted to specific readers, the most common questions that publishing houses ask prospective authors is the size of the potential demand for the book and whether the textbook in question has content that is appropriate for the latest development in the national curricula. Publishers' rational 
calculation is based on whether the book will generate sufficient revenue to cover production and marketing costs, and thus tend to be rigid in the requirements set for authors.

Indeed, authors play a significant role in determining the content of a textbook. Some authors opted not to follow the dictates and demand of publishers on what to include in their textbooks. For authors who are keen on fulfilling certain ideals that go beyond the pursuit of profits, publishing their books with small publishers is a good alternative. Sometimes local and small publishers as well as a publisher that belongs to a local univerity provide a better alternative because of the flexibility and ease that prospective authors have in updating the contents of their books as needs arise and low prices for books that make them affordable to students.

In addition, authors of citizenship education textbooks do not write books solely on the basis of government regulations and directions but use their judgement and understanding to determine both the content and the way it is presented in the body of the textbook. In many cases, institution of employment influence content and values that authors emphasize in books. For example, authors at Muhammadiyah University are expected to convey the Muhammadiyah's vision of a more Islamic society and citizenship. The influence of institutions is also evident in books authored by lecturers in UINs and Lemhanas institutions.

Cultural context of the reader is also an important factor that influences the content of textbooks. For example, a teaching staff in Medan considered a textbook on citizenship education authored by Ubaedillah and Rozak (2012), Pendidikan Kewarganegaraan (Civic Education): Pancasila, Demokrasi, HAM, dan Masyarakat Madani too "Islamic." Perhaps in response to the criticism, authors of the textbook in its latest edition (2015) removed Arabic language characters as well as included
Pancasila in the book title which was also an act that was aimed at incorporating the latest development in the national curricula on citizenship education that reinstated Pancasila as a compulsory subject.

Moreover, unlike during the New Order regime, teaching staff now have the autonomy to determine textbooks and the teaching modules they consider appropriate for their classes. They may "...accept, reinterpret, and reject what counts as legitimate knowledge" (Apple 1992, p. 10). For example, a teacher at Muhammadiyah University in Medan uses several nationally acclaimed textbooks as a source of reference for his citizenship education class. He uses Pendidikan Kewarganegaraan untuk Perguruan Tinggi (2007) by Kaelan and Zubaidi as an important reference, which he supplements with another book titled Pendidikan Kewarganegaraan by Dwi Winarno (2007) and Pendidikan Kewarganegaraan by Sumarsono (2006). On the theme of human rights, the same teacher preferred to use Demokrasi, HAM dan Masyarakat Madani (2008) by Ubaedillah and Rozak, which has since become his main reference textbook. In addition, the teacher included a textbook that was published by Muhammadiyah on his reading list to equip his students with a more Islamic perspective. What is true, however, is that with the exception of the Muhammadiyah textbook, teaching staff in other universities chose the same combination of textbooks, regardless of their ideological background.

Interestingly, to select a textbook, teachers of citizenship education do not only pay attention to its contents, information and themes, but also the credibility of the author. A teaching staff from USU, for example, uses a book authored by Dwi Winarno (2010) because the author attended a citizenship education course for teaching staff organized by Dikti, which was a good sign that the author had the knowledge and expertise required to write a book on citizenship education. In addition, 
despite disagreeing with some parts the book, the teacher still uses Ubaedillah's book (2012) because of the universal vision of human rights the author highlights. Another educator from Unimed considers Winarno's book Paradigma Baru Pendidikan Kewarganegaraan (2013) as the most appropriate text for his students. The book, according to the educator, provides good grounding of good citizenship education and understanding of civics as science. As he also personally knew the author, he was convinced that the perspective of the author is in line with his.

Finally, there is a significant practice that also highlights cross boundaries between educational institutions. Citizenship education classes are generally large $\mathrm{e}^{17}$, and it is not rare for educators to request assistance from their colleagues from other state or private universities, both with more secular and religious learning curricula. Such practice does not only demonstrate the fluidity of the boundaries between administrations in more secular and religious institutions, but also underscores the possibility that the process fosters the sharing and exchange of knowledge and values as well as the emerging contesting views of what constitutes a nation and a good citizen.

\section{Discussion}

Previous studies on education in Indonesia provide considerably rich findings on the development of education related policies, including changes in curricula and best practices on knowledge transmission toward preparing students for modernity. Unlike history textbooks of which importance lies in the need to maintain a continuity in national

\footnotetext{
${ }^{17}$ For example, the team of teaching staff of the Philosophy Department at Universitas Gadjah Mada had to teach 7000-8000 students in December 2014 and in the following year, the number surged to 9000 new students. Consequently, the teaching staff had to teach six classes of at least 60, 80 and even 110 students per year.
}

memory, civic textbooks are "deliberately written with the future in mind;" they aim to construct responsible individuals in their anticipated collectivities (Soysal et al., 2005, p. 12). Indeed, citizenship education is a context specific course, with its content frequently reformulated and re-shaped in accordance with changes in cultural and political settings. On the one hand, citizenship education may represent an ideal way of balancing unity and diversity within and beyond national boundaries (Banks, 2004). On the other hand, citizenship education is implemented for "forming social and political identity and giving young people the tools, they need to become active citizens" (Castles, 2004). It is understandable that to many national governments, citizenship education plays an important role for inculcating civic nationalist sentiments in the hearts and minds of the younger generation (Faucher, 2006).

In Indonesia, since 1998, the advent of democratization has ushered in a shift in the values embedded in the Indonesian national education system, in part induced by a pendulum swing in education policy from militaristic and authoritarianism New Order style to a more democratic mode of postNew Order governance paradigm (Jackson \& Bahrissalam, 2007; Song, 2008). Initiatives to build a new citizenship education emerged soon after the collapse of the authoritarian New Order regime (Azra, 2007; Jackson \& Bahrissalim, 2007; Kraince, 2007; Pohl, 2009). However, within the transition to-and the consolidation of-democracy, some studies indicate that university students show stronger religious than ethnic identification (Subagya, 2015, p. 224), and despite the multiculturality of Indonesia, public schools are yet to develop religious tolerance (Parker, 2010). Moreover, drawing on lessons from citizenship education textbooks, several studies ${ }^{18}$ have also identified

\footnotetext{
${ }^{18}$ On national history, among the existing studies, one identifies that despite regime changes, the New Order's militaristic narrative persists in history textbooks
} 
the multiplicity of emerging views in the content of the new citizenship education (Jackson \& Bahrissalim, 2007, p. 50). At least three contesting national imaginaries ${ }^{19}$ are vying for the dominance of the narratives of who we are as a nation and what good citizen should look like (Eddyono, 2018).

This paper contributes to the discussion by highlighting the concept of an intertwining of educational dualism in post-New Order Indonesia as vital to understanding the process of emerging contesting discourses on nationalism and the ideal citizen that is characterizing citizenship education today. Nurturing more modern yet religious students within an intertwined educational dualism underscores the reality that the state schools with a more secular learning curricula are not the sole source of references for people's education. Islamic education as the cornerstone of Muslim experience that is acquired through Islamic schools offers "a unique platform for addressing the question of how to carry Muslims forward into modernity at once plural and open-minded yet religious" (Hefner, 2010, p. 144). Yet, as Jackson and Parker note (2008), “...modernity poses huge complex questions about authority and truth, about sources of knowledge, the role of divinity and faith, political legitimacy, the proper relations of the state and religion and how education mediates these two realms" (p. 46).

(Purwanta, 2017). Another study highlights that attempts have been made to change the representations of the past in selected national events (Suwignyo, 2014) to diverge readers attention from the responsibility of the New Order regime pertaining to the mass killing in 1960s.

19 These include the state-centered, citizen-centered, and ummah-centered narratives. The contesting narratives of the nation and the ideal citizenship, however, neither necessarily reflect rigid typologies that encapsulate existing narratives on citizenship education in postSuharto Indonesia nor do they suggest that educators in relatively more secular learning schools use teaching materials that are different from those that their colleagues in more Islamic leaning schools use (Eddyono 2018).
The intertwining of educational dualism provides a better understanding of the context of Indonesian democracy and nation building, and the high likelihood of finding a common ground albeit ideological differences. Contextualizing citizenship education within an intertwined education dualism in Indonesiawhich involves both competition as well as the mixture of cross cutting actors, ideas, and the meeting point of networks - provides ways to understand how social movements that have the goal of transforming society either through more Islamic or to a more secular learning direction, attempt to achieve that goal through national education.

\section{Conclusion}

Using the concept of an interlinked or interwoven educational dualism, this study underlines the implausibility of a singular and uniform tenet of nationhood and citizenship in citizenship education in post-New Order Indonesia. While acknowledging the protracted tension that characterizes contested knowledge and values within an intertwined dualism of education in Indonesia, this study further highlights the possible interactions among actors, networks- building, and individual as well as institutional collaborations.

Two recommendations are conceivable. First, there is the urgency to nationally evaluate the current citizenship education curricula and its implementation within the context of the intertwined educational dualism in Indonesia. Secondly, there is also the need to assess whether core courses in the national curricula (Mata Kuliah Inti/MKI) in higher education, involving religion, Bahasa Indonesia, Citizenship Education, and Pancasila constitute a relevant response of the need to equip the young with the ability to become good citizens. Consequently, core courses in the national curricula (Mata Kuliah Intil $M K I$ ) in higher education should be designed and implemented in a manner that considers 
issues of democracy, multiculturalism, and tolerance.

\section{Acknowledgement}

The author is grateful to the JSP anonymous reviewers for their invaluable comments prior to the final version of this paper. Despite their priceless commentaries, however, any shortcoming in this study is her responsibility alone. The author is also indebted to Dr. Andika Fajar, the head of the Center of Data for Higher Education (Pangkalan Data Pendidikan Tinggi/PDDikti), the Ministry of Technology and Higher Education (Menristekdikti) of the Republic of Indonesia for allowing the use of the unpublished data of the numbers of citizenship education programs, teaching staff, and students enrolled at the undergraduate and graduate levels in Indonesia in September 2017 for this study.

\section{References}

Apple, M. W. (1992). The text and cultural politics. Educational Researcher, 21(7), 411-419.

Azra, A. (2007). Islamic Legal Education in Modern Indonesia. In R. M. Feener \& M.E. Cammack (Eds.), Islamic Law in Contemporary Indonesia, Ideas and Institutions. Massachusetts: Islamic Legal Studies Program, Harvard Law Shool, Harvard University Press.

Banks, J. A. 2004. Introduction: democratic citizenship education in multicultural societies. In J. A. Banks (Ed.), Diversity and Citizenship Education. San Fransisco: Jossey-Bass.

Bénêi, V. (2005). Introduction: manufacturing citizenship-confronting public spheres and education in contemporary worlds. In V. Bénêi (Ed.), Manufacturing citizenship: education and nationalism in Europe, South Asia, and China. London, New York: Routledge, Taylor and Francis Group.
Buchori, M. \& Malik, A. (2004). The Evolution of Higher Education in Indonesia. In P. G. Altbach \& T. Umakoshi (Eds.), Asian Universities: Historical Perspectives and Contemporary Challenges. Baltimore, London: The Johns Hopkins University Press.

Castles, S. (2004). Migration, citizenship, and education. In J. A. Banks (Ed.), Diversity and citizenship education. San Fransisco: Jossey-Bass.

Eddyono, S. (2018). The representations of Indonesianness in post-new order Indonesia (1998-2016) (Doctoral dissertation, University of Pittsburgh, 2018). Pittsburgh: USA: University of Pittsburgh.

Elson, R.E., (2009). "Another Look at the Jakarta Charter Controversy of 1945." Indonesia 88 (October):105-30.

Faucher, C. (2006). Popular discourse on identity politics and decentralization in Tanjung Pinang public school. Asia Pacific Viewopoint, 47(2), 273-85.

Groeneboer, K. (1998). Gateway to the west: The Dutch language in colonial Indonesia 1600-1950. Amsterdam: Amsterdam University Press.

Hefner, R.W. (2010). Muslim schools, social movements, and democracy in Indonesia. In M. S. Merry \& J. A. Milligan (Eds.), Citizenship, identity, and education in Muslim communities. New York: Palgrave Macmillan.

Jackson, E., \& Bahrissalim. (2007). Crafting a new democracy: civic education in Indonesian Islamic universities. Asia Pacific Journal of Education, 27(1), 41-54.

Jackson, E., \& Parker, L. (2008). 'Enriched with knowledge': modernisation, Islamisation and the future of Islamic education in Indonesia. Review of Indonesian and Malaysian Affairs, 42(1), 21-53.

Kraince, R. G. (2007). Islamic Higher Education and Social Cohesion in Indonesia. Prospects, 37(3), 345-356. 
Lemhanas. (1992). Kewiraan untuk mahasiswa. Jakarta: PT Gramedia.

Liddle, R. W., \& Mujani, S. (2013). Indonesian democracy: from transition to consolidation. In Künkler, M. \& Stepan, A. (Eds.), Democracy \& Islam in Indonesia. New York: Columbia University.

Lukens-Bull, R.A. (2001). Two sides of the same coin: modernity and tradition in Islamic education in Indonesia. Anthropology $\mathcal{E}$ Education Quarterly, 32(3), 350-372.

Murray, R. T. (1988). The Islamic revival and Indonesian education. Asian Survey 28(9), 897-915.

Parker, L. \& Raihani, R. (2011). Democratizing Indonesia through education? Community participation in Islamic schooling. Educational Management Administration \& Leadership, 39(6), 712-732.

Parker, L. (2010). Some inspirational efforts are being made to promote inter-religious understanding, but state schools are way behind. Inside Indonesia, 102(Oct-Dec), 1-7. Retrieved from www.insideindonesia.org/ teaching-religious-tolerance?

Pohl, F. (2009). Interreligious harmony and peacebuilding in Indonesian Islamic education. In C. J. Nontiel \& N.M. Noor (Eds.), Peace psychology in Asia. Springer Science and Business Media, LLC.

Purwanta, H. (2017). Militeristic discourse in secondary education history textbooks during and after the Soeharto era. Journal of Educational Media, Memory, and Society Spring, 9(1), 36-53.

Raihani. (2014). Creating multicultural citizens: a portrayal of contemporary Indonesian education. London, New York: Routledge.

Raillon, F. (2011). The return of Pancasila: secular vs. Islamic norms, another look at the struggle for state dominance in Indonesia. In M. Picard \& R. Madinier (Eds.). The politics of religion in Indonesia: syncretism, orthodoxy, and religious contention in Java and Bali. London, New York: Routledge.
Riessman, C. K. (2008). Narrative methods for the human sciences. Thousand Oaks, New Delhi, London, and Singapore: Sage Publications Ltd.

Rosidin, D. N. (2013). Muslim fundamentalism in educational institutions: a case study of Rohani Islam in high schools in Cirebon. In J. Burhanudin \& K. van Dijk (Eds.) Islam in Indonesia: contrasting images and interpretations. Amsterdam: ICAS/ Amsterdam University Press.

Sirozi, M. (2004). Secular-religious debates on the Indonesian national education system: colonial legacy and a search for national identity in education. Intercultural Education, 15(2), 123-137.

Picard, M., (2011). “Introduction: 'Agama, 'Adat', and Pancasila." In R. Madinier \& M. Picard. The Politics of Religion in Indonesia: Syncretism, Orthodoxy, and Religious Contentions in Java and Bali. Oxon and New York: Routledge.

Ramage, D.E., (1995). Politics in Indonesia: Democracy, Islam and the Ideology of Tolerance. London and New York: Routledge.

Song, S.W. (2008). Back to basics in Indonesia? Reassessing the Pancasila and Pancasila state and society, 1945-2007. (Doctoral dissertation, Ohio University, 2008). Ohio, USA: Ohio University.

Soysal, Y. N., Bertilotti, T., \& Mannitz, S. (2005). Projections of identity in French and German history and civic textbooks. In H. Schissler \& Y. N. Soysal (Eds.), The nation Europe and the world: textbooks and curricula in transition. New York, Oxford: Berghahn Books.

Subagya, Y.T. (2015). Support for ethno-religious violence in Indonesia. Yogyakarta, Nijmegen: Universitas Sanata Dharma and Radbound University.

Suwignyo, A. (2014). Indonesian national history textbooks after the New Order: what's new under the sun?. Bijdragen 
tot de Taal, Land, en Volkenkunde, 170(1), 113-131.

Ubaedillah, A. \& Rozak, A. (2012). Pendidikan kewarga[negara] dan civic education: Pancasila, demokrasi, HAM, dan masyarakat madani. Jakarta: Indonesian Center for Civic
Education (ICCE) UIN Syarif Hidayatullah Jakarta and Prenada Media Group.

Yusuf, M. \& Sterkens, C. 2015. Analysing the state's laws on religious education in post-New Order Indonesia. Al-Jāmi'ah: Journal of Islamic Studies, 53(1), 105-130. 